OECD Environment Working Papers No. 75

\title{
Greening Household Behaviour and Food
}

\author{
Katrin Millock
}

https://dx.doi.org/10.1787/5jxrclntbvs0-en 
Organisation de Coopération et de Développement Économiques

Organisation for Economic Co-operation and Development

10-Dec-2014

ENVIRONMENT DIRECTORATE

English - Or. English

\section{ENVIRONMENT WORKING PAPER No. 75 - GREENING HOUSEHOLD BEHAVIOUR AND FOOD}

By Katrin Millock (1)

(1) CNRS, Paris School of Economics, France.

OECD Working Papers should not be reported as representing the official views of the OECD or of its member countries. The opinions expressed and arguments employed are those of the author(s).

Authorised for publication by Simon Upton, Director, Environment Directorate.

JEL Classification: C51, D11, D12, Q18, Q58.

Keywords: Organic fruits and vegetables, animal welfare, attitudes, behaviour, labelling, willingness-to-pay, household survey.

OECD Environment Working Papers are available at www.oecd.org/env/workingpapers.htm

JT03368379

Complete document available on OLIS in its original format

This document and any map included herein are without prejudice to the status of or sovereignty over any territory, to the delimitation of international frontiers and boundaries and to the name of any territory, city or area. 


\section{OECD ENVIRONMENT WORKING PAPERS}

"OECD Working Papers should not be reported as representing the official views of the OECD or of its member countries. The opinions expressed and arguments employed are those of the author(s).

OECD Working Papers describe preliminary results or research in progress by the author(s) and are published to stimulate discussion on a broad range of issues on which the OECD works.

This series is designed to make available to a wider readership selected studies on environmental issues prepared for use within the OECD. Authorship is usually collective, but principal author(s) are named. The papers are generally available only in their original language -English or French- with a summary in the other language.

Comments on OECD Working Papers are welcomed, and may be sent to:

OECD Environment Directorate, 2, rue André Pascal, 75775 PARIS CEDEX 16, France or by e-mail to env.contact@oecd.org

OECD Environment Working Papers are published on www.oecd.org/env/workingpapers.htm

This document and any map included herein are without prejudice to the status of or sovereignty over any territory, to the delimitation of international frontiers and boundaries and to the name of any territory, city or area.

The statistical data for Israel are supplied by and under the responsibility of the relevant Israeli authorities. The use of such data by the OECD is without prejudice to the status of the Golan Heights, East Jerusalem and Israeli settlements in the West Bank under the terms of international law.

\section{(C) OECD (2014)}

You can copy, download or print OECD content for your own use, and you can include excerpts from OECD publications, databases and multimedia products in your own documents, presentations, blogs, websites and teaching materials, provided that suitable acknowledgment of OECD as source and copyright owner is given.

All requests for commercial use and translation rights should be submitted to rights@oecd.org 


\begin{abstract}
This report focuses on households' behaviour in relation to food consumption. It presents the results of follow-up econometric analysis of the 2011 OECD Survey on Environmental Policy and Individual Behaviour Change (EPIC). This report complements the overview of the survey data provided in the publication OECD (2014). It studies expenditure and willingness-to-pay (WTP) for organic food and food labelled as taking animal welfare into account.

The main findings are that some socio-demographic variables explain organic food purchases and expenditures: the presence of children under 5, age and income. Environmental attitudes and behaviour (membership in environmental organizations) have large marginal effects on expenditure on organic fruit and vegetables. In addition, respondents that rank environmental concerns before health concerns in their food choices have higher expenditure on organic fruit and vegetables, all else equal. The WTP for organic food increases with years of education and income, as in other studies. Respondents that rank environmental concern higher than health concerns in their food choices are also willing to pay more for organic produce, as are urban residents compared to rural residents. The determinants of expenditure and WTP for food that takes animal welfare into account have been less analysed in earlier studies. Fewer variables are statistically significant. Income is never significant in explaining expenditure or WTP for products with animal welfare labels. The marginal effects of the environmental attitudinal variables are larger than for organic fruit and vegetables. There is a possibility, though, that respondents to the EPIC survey interpreted organic largely as including animal welfare and the specific numbers relating to animal welfare expenditures and WTP must be interpreted with caution. The conclusions on organic food are more robust and corroborated by existing results. Food waste is becoming an issue in some OECD countries and the EPIC survey provides some unique comparative data on this topic. We find that the decision to compost household food waste is encouraged by the household paying a waste fee based on the volume or weight of waste collected. Another policy conclusion is to target campaigns to diminish food waste towards younger individuals and households with young children.
\end{abstract}

JEL Classification: C51, D11, D12, Q18, Q58.

Keywords: Organic fruits and vegetables, animal welfare, attitudes, behaviour, labelling, willingnessto-pay, household survey. 


\section{RÉSUMÉ}

Ce rapport est consacré au comportement des ménages en matière d'alimentation. Il présente les résultats de travaux d'analyse économétrique qui s'inscrivent dans le prolongement de l'enquête sur la politique de l'environnement et le comportement individuel (EPIC) réalisée par l'OCDE en 2011. Ce rapport complète la synthèse des données de l'enquête présentée dans l'ouvrage OCDE (2014). Il est centré sur l'étude des dépenses réalisées et du consentement à payer (CAP) pour acquérir des aliments biologiques ou étiquetés comme respectant le bien-être des animaux.

Son principal résultat est que certaines caractéristiques sociodémographiques expliquent les achats et les dépenses liés aux aliments biologiques : présence dans le foyer d'enfants de moins de 5 ans, âge et revenu. Les attitudes et les comportements à l'égard de l'environnement (comme l'adhésion à des organisations de protection de l'environnement) ont un important effet marginal sur les dépenses consacrées à l'achat de fruits et légumes bio. En outre, toutes choses égales par ailleurs, les répondants qui accordent plus d'importance à l'environnement qu'à la santé dans le cadre de leurs choix alimentaires sont disposés à consacrer davantage d'argent à l'achat de fruits et légumes bio. Conformément aux résultats d'autres études, plus le niveau d'études et de revenu est élevé, plus le consentement à payer pour des aliments bio augmente. Les répondants pour qui les considérations environnementales pèsent davantage sur les choix alimentaires que les questions de santé, ainsi que les individus résidant en milieu urbain, sont également prêts à payer davantage pour des produits bio. Le degré auquel le bien-être animal influence les choix des ménages a été plus rarement abordé dans les études antérieures. Il y a moins de variables significatives d'un point de vue statistique en ce qui concerne les dépenses et le consentement à payer pour de la viande et de la volaille étiquetées comme respectant le bien-être des animaux. Le revenu, par exemple, n'est jamais significatif. À l'inverse, les effets marginaux des variables de comportement environnemental sont supérieurs à ce qui est constaté pour les fruits et légumes biologiques. Il est tout de même possible que les répondants aient le sentiment que l'agriculture biologique englobe plus largement la notion de bien-être animal, et c'est pourquoi les chiffres relatifs aux dépenses et au consentement à payer dans ce domaine doivent être interprétés avec prudence. Les observations liées aux aliments biologiques sont pour leurs parts plus fiables, car corroborées par de précédents résultats. Les déchets alimentaires sont en train de devenir un problème dans certains pays de l'OCDE et l'enquête EPIC fournit quelques données comparatives inédites à ce sujet. Il apparaît que le compostage des déchets alimentaires ménagers est encouragé lorsque les ménages paient des redevances calculées selon le volume ou le poids des déchets collectés. Autre conclusion pratique : les campagnes d'information visant à faire baisser le volume de déchets alimentaires doivent cibler en priorité les jeunes et les ménages comptant des enfants en bas âge.

Classification JEL : C51, D11, D12, Q18, Q58.

Mots-clés: fruits et légumes biologiques, bien-être animal, attitudes, comportement, étiquetage, consentement à payer (CAP), enquête ménages. 


\section{TABLE OF CONTENTS}

ABSTRACT

FACTORS AFFECTING THE USE OF LABELS AND THE LEVEL OF TRUST ….................................

FACTORS AFFECTING EXPENDITURE ON FRUIT AND VEGETABLES WITH ORGANIC

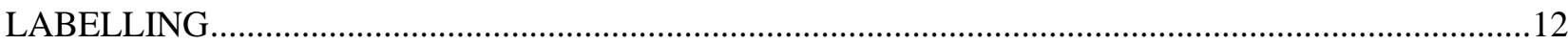

FACTORS AFFECTING EXPENDITURE ON MEAT AND POULTRY WITH ANIMAL WELFARE

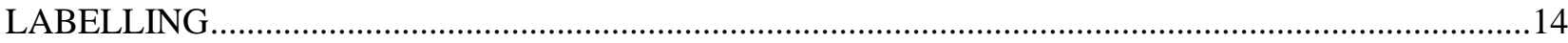

FACTORS AFFECTING THE WILLINGNESS TO PAY FOR FRUIT AND VEGETABLES WITH

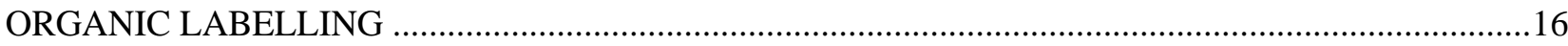

FACTORS AFFECTING THE WILLINGNESS TO PAY FOR MEAT AND POULTRY WITH ANIMAL

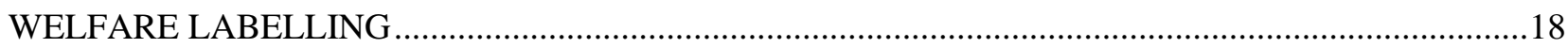

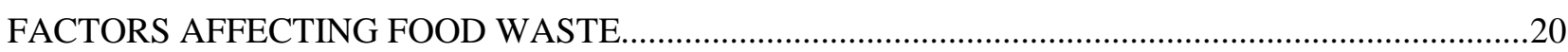

FACTORS AFFECTING THE DECISION TO COMPOST FOOD WASTE …......................................22

DISCUSSION AND COMPARISON WITH PREVIOUS RESULTS ...................................................24

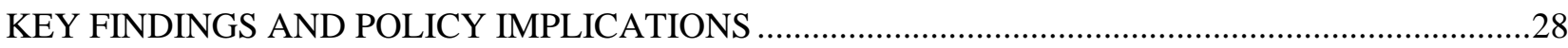

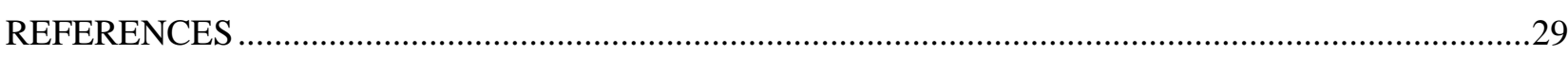

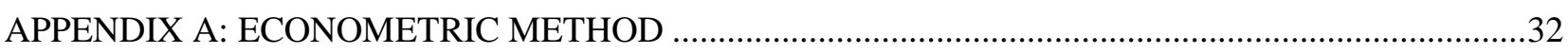

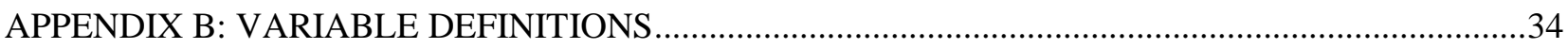

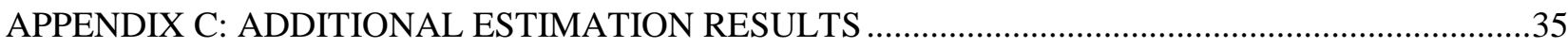

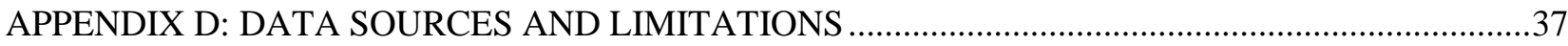

\section{Tables}

Table 1. Marginal effects of factors explaining trust in and use of the national organic label .............9

Table 2. Marginal effects of factors explaining trust in and use of the (old) EU organic label...........10

Table 3. Estimation results of the factors explaining the expenditure share on organic fruit and vegetables 13

Table 4. Estimation of the factors explaining the probability of buying and expenditure share on animal-welfare labelled meat and poultry - Pooled sample ..................................................................15

Table 5. Factors explaining WTP for organically labelled fruit and vegetables................................17

Table 6. Marginal effects of factors explaining WTP for animal welfare labelled meat and poultry tobit estimation on the pooled sample.

Table 7. Factors explaining the amount of declared food waste. 
Table 8. Factors explaining the composting of food waste ……...................................................22

Table 9. Summary of results of the most recent studies on organic food..........................................26

Table 10. Determinants of WTP for animal welfare. Summary of results of previous studies .............27

Table B.1 Definitions of the variables used in the estimations ...................................................34

Table C.1 Marginal effects of factors explaining trust in and use of either the old or the new EU

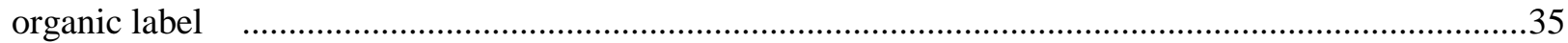

Table C.2 Marginal effects of factors explaining the trust and use of either Australian organic label35

Table C.3 Marginal effects of factors explaining the trust and use of the animal welfare label in the

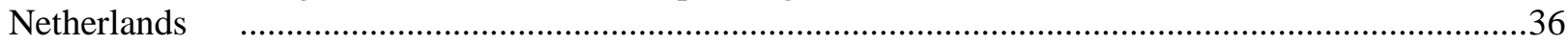

Table C.4 Factors explaining WTP for animal welfare labelled meat and poultry in the Netherlands36

\section{Figures}

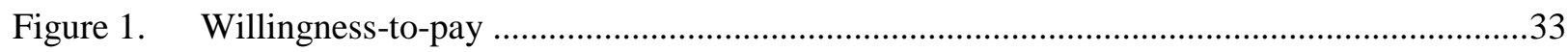


ENV/WKP(2014)13

\section{INTRODUCTION}

In a context of growing population, income increases and lifestyle changes in large populated countries, food production and consumption exert a growing pressure on the environment. At the same time, a number of food scares following outbreaks of BSE (mad-cow disease), dioxin-contaminated chicken, listeria and salmonella contamination have raised consumers' concern about food quality. Concerns about the environment and concerns about product safety and health have induced some consumers to change their consumption patterns towards more environmentally-friendly products including organic food.

Product characteristics such as freshness and taste are experience attributes and can thus be ascertained after consumption. The use of organic production methods, or production that takes animal welfare into account, cannot be assessed directly by the consumer, though, and represent credence attributes. For such characteristics, labelling is necessary, and the consumers' recognition and trust in the labels will determine consumption of such products, in addition to the usual consumer socio-economic characteristics and attitudes and behaviour. When measuring specific trust in the food production system and trust in the regulatory agencies, Williams and Hammitt (2000) found that a low value on the index measuring trust made the individual more likely to be an organic buyer. Several recent studies show that consumers are willing to pay for animal welfare labelling (Tonsor and Wolf, 2011; Gracia, Loureiro and Nayga, 2011).

The literature has shown that organic food demand depends on the demographic and socio-economic characteristics of the consumer and her household, on consumer information (through labels, for example) and trust, as well as on attitudes and environmental behaviour. Despite high price premiums for organic food, consumption does not necessarily increase with income and the literature contains mixed results on income. Other household characteristics may be more important, such as household size or the presence of young children in the household. Environmental and health attitudes are known to be important in organic food consumption, but few studies actually measure consumers' attitudes and environmental behaviour. The OECD survey can thus shed some new light on the determinants of organic food consumption since it contains information on both demographic and socio-economic characteristics and stated attitudes and behaviour of the respondent. Less is known about the demand for animal welfare labelled products and the OECD survey permits to clarify and compare the factors that are important for buying such products. Above all, lack of trust in the certification and labelling process is often claimed to be one of the largest barriers against the diffusion of organic food (Giannakas, 2002). We will analyse the factors that determine why consumers trust a label or use it in their purchasing decisions.

The report thus analyses the factors that determine consumption of organic food and food labelled animal welfare. The one issue where policy can intervene directly - the label and trust in it - is analysed in section 2. Section 3 analyses the determinants of expenditure on organic food, while Section 4 presents the analysis of expenditure on food labelled animal welfare. The factors affecting willingness to pay (WTP) are analysed in sections 5 and 6. Finally we also study the factors that explain food waste (Section 7) and the household's choice to compost (Section 8). Section 9 compares the results with the existing literature and the previous EPIC survey of 2008. Section 10 concludes by discussing the main results and policy implications. Any estimation results that are not presented directly in the text can be found in the appendix, together with a description of the method and the variables used in the analysis. 


\section{FACTORS AFFECTING THE USE OF LABELS AND THE LEVEL OF TRUST}

\section{The set of labels displayed in the survey}

The analysis and the conclusions drawn are based on the set of labels that was displayed in the EPIC survey. The list of the organic-food labels selected for the survey was established in close relation with government representatives taking part in the Advisory Committee set-up for this project in order to ensure that the most pertinent ones are shown to the respondents. Other more secondary labels which exist in a number of countries were not presented.

When a label was recognized by a respondent, he/she was asked to state whether he understands its meaning, trusts the label and uses it in purchasing decisions. The analysis focuses on the use of the label conditional on recognising it as this is a main question of interest to policy-makers. Results on what factors explain whether a respondent trusts a label or not are also presented.

In fact, among the selected labels, most were understood. $90 \%$ or more of respondents who said they recognized the label also claimed they understood it. Lower levels of understanding were only displayed for the new European Union (EU) organic label which was introduced in 2010. The use of the national organic label ranges from $38 \%$ among the Israeli $^{1}$ respondents, to $75 \%$ among Korean respondents. Australia is the only country in which two different national labels for organic food were displayed. 52\% of those who recognised the "Australian Certified Organic" reported using the label compared to more than $60 \%$ for the "NASAA Certified Organic". We analyse the national and European organic food labels presented to the respondents of the EPIC survey. In the four EU countries, the new and the old organic labels were shown to respondents. Results clearly indicate that the old EU label that was used on a voluntary basis is still much better known than the new one in the four EU countries where both labels were presented to respondents: France, the Netherlands, Spain and Sweden.

Descriptive statistics on the EPIC survey results show that use of the old EU label ranges from $40 \%$ in Sweden to $65 \%$ in Spain. The use of the new EU label ranges from $16 \%$ in Sweden, to $48 \%$ in Spain. The Netherlands is the only country in which a label for animal welfare was displayed and $60 \%$ of the Dutch respondents declared using this label.

\section{Estimation results}

Simple probit estimations on trusting and using the label, among those who said they recognized it, were run for the different types of labels on the sample of countries in which the label exists. The dependent variable equals one when the respondent has declared trusting the label or declared using the label in his purchase decisions, and zero otherwise. We focus on the use of the label since it is the most policy relevant. We also present results on the factors determining trust in the label for the national organic label, the label that generally is the most trusted and used among the organic labels displayed. The estimations include country fixed effects ${ }^{2}$ which are not shown here and use of sample weights. ${ }^{3}$

\footnotetext{
${ }^{1}$ The statistical data for Israel are supplied by and under the responsibility of the relevant Israeli authorities. The use of such data by the OECD is without prejudice to the status of the Golan Heights, East Jerusalem and Israeli settlements in the West Bank under the terms of International law.

${ }^{2}$ Fixed country effects control for unobserved factors that may influence organic consumption in each country: institutions, market conditions, etc.
} 


\section{National labels}

The probit estimation results of trusting and using the national organic label are presented in Table 1 . The estimations are done on the pooled sample with the dependent variable being the national organic label.

Table 1. Marginal effects of factors explaining trust in and use of the national organic label

\begin{tabular}{|c|c|c|}
\hline Variables & Trust the label & Use the label \\
\hline Age of respondents & -0.001 & $0.003^{* * *}$ \\
\hline $\begin{array}{l}\text { Education } \\
\text { (number of years completed after high school) }\end{array}$ & 0.001 & $0.009^{\star *}$ \\
\hline $\log \mathrm{INC}^{4}$ & -0.014 & 0.015 \\
\hline $\begin{array}{l}\text { Gender }^{5} \\
(\text { male }=1)\end{array}$ & $-0.065^{\star \star \star}$ & $-0.091^{\star \star \star}$ \\
\hline Participation in environmental organisation & 0.037 & $0.210^{* * *}$ \\
\hline Score on "trust" index ${ }^{6}$ & $0.070^{\star \star *}$ & $0.056^{\star * \star}$ \\
\hline $\begin{array}{l}\text { Ranking of environmental concerns high } \\
\text { compared to other issues facing the world }\end{array}$ & $0.074^{\star \star *}$ & $0.095^{\star \star \star}$ \\
\hline $\begin{array}{l}\text { Area of residence } \\
(\text { town }=1)\end{array}$ & 0.009 & 0.011 \\
\hline Number of observations & 4676 & 4990 \\
\hline Prob>chi2 & 0.000 & 0.000 \\
\hline Pseudo R2 & 0.101 & 0.103 \\
\hline
\end{tabular}

The survey data shows particularly interesting results concerning use of the label. Fewer variables are statistically significant to explain respondents' responses to recognizing, understanding and trusting the label. The three variables that consistently explain trust in the organic label are: being female, having a high score on the index measuring trust in information sources providing information about the environmental impacts of products and, lastly, ranking environmental concerns as the most serious issue facing the world today. The trust index also explains use of the organic label.

\footnotetext{
${ }^{3}$ The sample weights adjust the observations in the pooled sample so that the number of observations reflects the actual ratios in the population of key variables. This ensures that the pooled sample is unbiased.

4 The variable that is used is the logarithm of imputed income (respondents only stated the interval of their household's income).

${ }^{5}$ A dummy variable (also known as binary variable) is one that takes the value 0 or 1 to indicate the absence or presence of some categorical effect (e.g. male/not male, etc.).

${ }^{6}$ The "trust" index is calculated as the average score of the answers to the question "How trustworthy do you consider the following sources with regard to information on claims about the environmental impacts of products?" with respect to scientists, environmental organizations, producer and consumer organizations, national or local government. Labels are national in some countries, and private in others or a mix. The average score on this question is used as a general measure of trust.
}

${ }^{7}$ Dummy variable that takes the value 1 if the respondent lives in an urban area and 0 otherwise. 
Results indicate that four main factors explain why a respondent uses the organic label. The probability to use the label increases when the respondents participates in environmental organizations, when the general trust index is high and when environmental concerns are ranked as the most serious issue facing the world. In all the estimations we have run on the different questions on labels, the only variable that is consistently significant is ranking environmental concerns as the most serious issue facing the world. It increases the likelihood of recognizing, understanding, trusting and using a label. Together with participation in environmental organizations, this variable has the largest marginal effect on organic label use, followed by gender. The likelihood to use the national organic label in purchasing decisions increases also as respondents are older and more educated, but the marginal effect of these demographic variables is smaller.

\section{New and old EU organic label}

Table 2 presents separate estimations on the recognition of the old EU organic label for the four EU countries involved in the 2011 EPIC survey: France, the Netherlands, Spain and Sweden. Results on trusting and using either of the new or old EU organic labels are presented in the Appendix (Table C.1). Just as for the national organic label, we find that male respondents are less likely to trust the old EU organic label. Respondents with a higher score on the general trust index and respondents ranking environmental concerns as the most important issue are more likely to trust the old EU organic label.

Table 2. Marginal effects of factors explaining trust in and use of the (old) EU organic label

\begin{tabular}{lcc}
\hline & Trust the label & Use the label \\
\hline Age of respondents & -0.000 & 0.001 \\
$\begin{array}{l}\text { Education } \\
\text { (number of years completed after high school) }\end{array}$ & 0.005 & $0.015^{\star *}$ \\
logINC & 0.022 & 0.023 \\
Gender & $-0.108^{* * *}$ & $-0.129^{\star * *}$ \\
(male=1) & & \\
Participation in environmental organisation & 0.034 & $0.147^{\star * *}$ \\
Score on "trust" index & $0.059^{* * *}$ & $0.041^{\star * *}$ \\
Ranking of environmental concerns high & $0.128^{\star * *}$ & $0.213^{\star * *}$ \\
compared to other issues facing the world & & 0.002 \\
Area of residence & -0.004 & \\
(town=1) & & 872 \\
Number of observations & 813 & 0.000 \\
Prob>chi2 & 0.000 & 0.074 \\
Pseudo R2 & 0.117 & \\
\hline
\end{tabular}

Note: ${ }^{* * *} p<0.01,{ }^{* *} p<0.05,{ }^{*} p<0.10$

Those that are more likely to use the label are respondents with more years of post-secondary schooling and that rank the environment as the most serious issue, and those who participate in environmental organizations. The main difference compared to using the national organic label is that age is not a statistically significant factor in explaining use of the old EU organic label. Given the small sample to do an analysis of the new EU label (only membership in an environmental organization and a high score on the general trust index statistically explains use of the new EU label), an alternative specification was tested with the dependent variable defined as using either the old or the new EU label. This estimation gives almost the same qualitative results as the estimation on the old EU organic label only and is presented in Table C.1 in Appendix C. The main differences compared to the results presented here are that 
age slightly increases the probability of using either the old or the new EU organic label and that exactly the same variables that explain label use also explain trust in the label.

\section{Australian national organic labels}

A separate estimation was also made on the Australian sample to look at the use of either of the two Australian national organic labels displayed in the EPIC 2011 survey. Results are presented in Table C.2 in Appendix C. Findings indicate that socio-demographic characteristics of respondents are not significant factors explaining the use of the labels. Gender is an exception and being male decreases the probability of using and also trusting the label. Participation in an environmental organisation and having a high score on the trust index both increase the likelihood of trusting and using the organic label. Ranking environmental concerns as the most important also increases the use of either of the two Australian organic labels shown in the survey.

\section{Dutch label on animal welfare}

The Netherlands is the only country where an animal welfare label was displayed to respondents. The estimation on the Dutch sample shows that the probability to use this label increases as the "trust" index defined earlier increases and with the ranking of environmental concerns as the most serious issue facing the world today. The marginal effects of attitudes are predominant for this label (see Table C.3 in Appendix C). Age is the only socio-demographic variable to be significant and has a negligible marginal effect. 


\section{FACTORS AFFECTING EXPENDITURE ON FRUIT AND VEGETABLES WITH ORGANIC LABELLING}

\section{$1 \quad$ The issue}

Respondents had to estimate the percentage of their household's food expenditure for fresh fruit and vegetables that is labelled as organic. The mean expenditure share in the EPIC 2011 survey is 23\%, ranging from $13 \%$ in Israel to $35 \%$ in Switzerland. These figures on expenditure shares have to be discussed with caution though, since they are stated by the respondents and not measured using scannerbased data. As shown in previous research, stated values in surveys tend to overestimate consumption and respondents to the EPIC survey may have misstated their consumption either because of mistaking food as organic or because of their using a broad definition of what is organic. In addition, respondents may have confused organic and animal welfare labelling when specifying the amount consumed. This issue is accounted for in the separate estimation made in the section 4 for the Netherlands, the only country for which an animal welfare label was displayed in the questionnaire.

\section{$2 \quad$ Estimation results}

Table 3 shows the results of the Tobit estimation of stated percentage of expenditure of fruit and vegetables that are organic, as defined by the household. We present both the estimated marginal effect on the probability to purchase organic and the estimated marginal effect on expenditures. This allows a comparison with the results in the literature where the two decisions often are estimated separately or in two stages. ${ }^{8}$ Here we only discuss the marginal effect on expenditures, since the results from the EPIC 2011 survey indicate that the same factors determine both the probability to buy organic and the level of expenditures. The household's reported expenditure share increases with income, age and the presence of children below 5 years of age. Respondents that rank environmental concerns before health concerns in their food choices also have higher stated expenditures on organically labelled fruits and vegetables. Expenditures also increase with the environmental concern index and with a high score on the trust index. We include as well separate measures of attitudes such as agreement with the statement "environmental impacts are frequently overstated" and agreement with the statement "environmental issues will be resolved in any case through technological progress". The estimation indicates that only disagreement with the first statement increases declared expenditures in a statistically significant manner.

\footnotetext{
${ }^{8}$ Like in the Tobit model or in the Heckman model.
} 
ENV/WKP(2014)13

Table 3. Estimation results of the factors explaining the expenditure share on organic fruit and vegetables

\begin{tabular}{|c|c|c|}
\hline & $\begin{array}{l}\text { Marginal effect on the probability of } \\
\text { buying organic }\end{array}$ & Marginal effect on expenditure \\
\hline Age of respondents & $0.002^{\star \star \star}$ & $0.082^{\star \star \star}$ \\
\hline $\begin{array}{l}\text { Education } \\
\text { (number of years completed } \\
\text { after high school) }\end{array}$ & -0.000 & -0.004 \\
\hline $\log I N C$ & $0.022^{* *}$ & $1.180^{\star \star}$ \\
\hline $\begin{array}{l}\text { Gender } \\
(\text { male }=1)\end{array}$ & 0.000 & 0.020 \\
\hline $\begin{array}{l}\text { Children in the household } \\
\text { (children }<5 \text { present }=1 \text { ) }\end{array}$ & $0.020^{*}$ & $1.097^{*}$ \\
\hline Score on "trust" index & $0.022^{\star * *}$ & $1.155^{\star * \star}$ \\
\hline $\begin{array}{l}\text { Ranking environmental } \\
\text { concerns before health } \\
\text { concerns }\end{array}$ & $0.034^{\star *}$ & $1.941^{*}$ \\
\hline $\begin{array}{l}\text { Ranking high on an index of } \\
\text { environmental concern }\end{array}$ & $0.023^{* * *}$ & $1.248^{\star * *}$ \\
\hline $\begin{array}{l}\text { Disagreement with the } \\
\text { statement "environmental } \\
\text { impacts are frequently } \\
\text { overstated" }\end{array}$ & $0.013^{* * *}$ & $0.675^{\star * *}$ \\
\hline $\begin{array}{l}\text { Disagreement with the } \\
\text { statement "environmental } \\
\text { issues will be resolved in any } \\
\text { case through technological } \\
\text { progress" }\end{array}$ & -0.001 & -0.027 \\
\hline $\begin{array}{l}\text { Area of residence } \\
(\text { town }=1)\end{array}$ & -0.006 & -0.322 \\
\hline $\begin{array}{l}\text { Number of observations } \\
\text { Prob }>\text { F } \\
\text { R-squared }\end{array}$ & & $\begin{array}{l}8337 \\
0.000 \\
0.013\end{array}$ \\
\hline
\end{tabular}

Note: ${ }^{* * *} p<0.01,{ }^{* *} p<0.05,{ }^{*} p<0.10$ 


\section{FACTORS AFFECTING EXPENDITURE ON MEAT AND POULTRY WITH ANIMAL WELFARE LABELLING}

\section{The issue}

An original contribution of the OECD EPIC 2011 Survey is to collect data on households' expenditures on food with animal welfare labelling. The existing literature on animal welfare is mainly comprised of willingness-to-pay (WTP) studies, and data is scarce on households' actual expenditures. The OECD survey results can thus shed some new light on this issue. Respondents had to estimate the percentage of their household's expenditure for meat and poultry that are labelled as taking animal welfare into account. The mean expenditure share was $32 \%$ in the EPIC 2011 survey. It ranges from $23 \%$ in Japan and Korea to 53\% in Switzerland. When interpreting the results, one has to keep in mind that the figures are stated expenditure shares, and not actual values from scanned purchases. As is well-known in the literature, hypothetical bias from surveys normally imply overestimated values (List and Gallet, 2001; Murphy et al., 2005). As will be shown in the section on the WTP for animal welfare, socio-economic variables are normally not found to be statistically significant in explaining WTP. Income and gender are exceptions. Higher income and being a male both increase the WTP in most previous studies.

Similar explanatory variables are used in the estimations on expenditure on meat and poultry labelled to take animal welfare into account as in the estimations for organic food expenditure. Animal welfare, like organic food, is a credence good in the sense that the qualities of the good cannot be observed by the consumer, even after consumption in contrast to experience goods, making it difficult to assess its utility. Since consumers cannot ascertain that animal welfare actually has been taken into account, trust in the stakeholders plays an important role (Nocella et al., 2010). The role of trust is assessed by including a variable measuring general trust towards different sources of information with regard to claims about the environmental impacts of products $^{9}$ (government, environmental organizations, etc). One added value of the OECD survey is that it measures attitudes towards the environment and food safety, as well as environmental habits. We can thus control for such factors, in addition to the effect of the usual socioeconomic variables.

We use the score on a general trust index as an explanatory variable in the analysis since the descriptive statistics showed a positive relation between a higher "trust" score and higher expenditure on animal-welfare labelled meat and poultry (see OECD, 2014). We use a Tobit estimation, which uses the same explanatory variables to estimate both the probability that the household purchases animal welfare labelled meat and poultry and the level of expenditures, if they are positive. The estimation is done on the entire pooled sample using sample weights and individual country fixed effects. A separate estimation is also done for the Netherlands, the only country for which an animal welfare label was displayed to the respondents. ${ }^{10}$ The full results are presented in Table C.4 in Appendix.

\footnotetext{
${ }^{9}$ Q27 in the EPIC 2011 questionnaire.

${ }^{10}$ Regardless of this small sample, label use or trust in the label cannot be used as an explanatory variable since they are likely to be endogenous to the main attitudinal explanatory variables that explain whether a household has positive expenditures on animal welfare-labelled meat and poultry.
} 
Estimation results

Table 4 indicates that the probability of buying animal-welfare labelled meat and poultry is mainly affected by whether or not respondents support or participate in the activities of an environmental organization. The expenditure share on animal welfare-labelled meat and poultry appears to increase with education and age, but to decrease if the respondent is male. Supporting or participating in an environmental organization has the highest marginal impact on expenditures, followed by the effect of gender and a high score on the trust index. Disagreement with the statement "environmental impacts are frequently overstated" also increases expenditures on animal welfare labelled products. ${ }^{11}$

Table 4. Estimation of the factors explaining the probability of buying and expenditure share on animalwelfare labelled meat and poultry - Pooled sample

\begin{tabular}{|c|c|c|}
\hline & $\begin{array}{l}\text { Marginal effect on the probability of } \\
\text { buying }\end{array}$ & Marginal effect on expenditures \\
\hline Age of respondents & $0.001^{*}$ & $0.041^{*}$ \\
\hline $\begin{array}{l}\text { Education (number of years } \\
\text { completed after high school) }\end{array}$ & $0.004^{*}$ & $0.232^{*}$ \\
\hline $\log I N C$ & 0.008 & 0.540 \\
\hline $\begin{array}{l}\text { Gender } \\
(\text { male }=1)\end{array}$ & $-0.040^{\star \star \star}$ & $-2.585^{\star \star \star}$ \\
\hline $\begin{array}{l}\text { Children in the household } \\
\text { (children }<5 \text { present }=1 \text { ) }\end{array}$ & 0.005 & 0.353 \\
\hline Score on "trust" index & $0.019^{* * *}$ & $1.254^{\star \star *}$ \\
\hline $\begin{array}{l}\text { Supporting the activities of an } \\
\text { environmental organisation }\end{array}$ & $0.079^{* * *}$ & $6.597^{\star \star \star}$ \\
\hline $\begin{array}{l}\text { Disagreement with the } \\
\text { statement "environmental } \\
\text { impacts are frequently } \\
\text { overstated" }\end{array}$ & $0.008^{*}$ & $0.496^{*}$ \\
\hline $\begin{array}{l}\text { Disagreement with the } \\
\text { statement "environmental } \\
\text { issues will be resolved in any } \\
\text { case through technological } \\
\text { progress" }\end{array}$ & -0.007 & -0.454 \\
\hline $\begin{array}{l}\text { Area of residence } \\
(\text { town }=1)\end{array}$ & -0.004 & -0.230 \\
\hline $\begin{array}{l}\text { Number of observations } \\
\text { Prob>F } \\
\text { R-squared }\end{array}$ & & $\begin{array}{l}6175 \\
0.000 \\
0.013\end{array}$ \\
\hline
\end{tabular}

The estimation results on the Dutch sample only (not shown here) indicate that having children under 5 decreases the expenditure on animal welfare labelled meat and poultry. Otherwise, only environmental attitudes increase expenditure in a statistically significant manner.

\footnotetext{
${ }^{11}$ Q26 in the EPIC 2011 questionnaire.
} 


\section{FACTORS AFFECTING THE WILLINGNESS TO PAY FOR FRUIT AND VEGETABLES WITH ORGANIC LABELLING}

\section{The issue}

Respondents were asked to state the maximum percentage price increase they would be willing to pay for fresh fruit and vegetables labelled as organic, compared to conventional products. The median WTP for fresh organic fruit and vegetables varies from a 5\% price increase in Australia and Canada, to a 23\% price increase in Korea. The corresponding mean WTP varies from 16\% in Australia and the Netherlands to $34 \%$ in Korea. Since the respondents were not reminded of their budget constraint in the WTP question, the conclusions presented here must be interpreted with caution, though. In addition, all hypothetical surveys may contain an overestimation of the WTP ${ }^{12}$.

A data error also had to be accounted for and this was done in two manners. ${ }^{13}$ First by estimating both a model of all countries and one with France and Switzerland excluded. The second test is to estimate two models: one where all values of WTP $=1 \%$ have been put to zero for France and Switzerland, and one keeping the raw data as it is. The estimation results indicate that the pooled results are rather robust to the data recording error for France and Switzerland.

\section{$2 \quad$ Estimation results}

In Table 5, we present only the results from the pooled estimation on the raw data (column 1) and also the estimation results for the same estimation excluding France and Switzerland (column 2). The results seem rather robust with respect to the data encoding error, at least qualitatively although the marginal effects change for some variables (such as being a member in an environmental organisation or living in an urban area versus a rural area). The one major difference is that the marginal effect of income has a positive effect on WTP on the pooled sample, which it does not have when France and Switzerland are excluded. The same occurs for education but only at a significance level of ' 0.10 ', indicating a $10 \%$ probability that the results are due to chance. The full sample estimation results for the 11 countries indicate that WTP for organic food increases with years of post-secondary education, income, participation in an environmental organisation and a higher score on the environmental concern index. We cannot include trust in the label in this estimation since it is endogenous, but we use a proxy - the score on a general trust index - and the WTP increases significantly with the score on the trust index. WTP decreases if the respondent is male. Respondents living in urban areas have a higher stated WTP than those living in rural areas. Finally, a respondent who ranks environmental concerns before health concerns in her/his food shopping choices has a higher WTP, all else equal, than someone who ranks health before environment or at an equally important level.

\footnotetext{
${ }^{12}$ List and Gallet (2001) estimate that hypothetical stated values are about three times higher than actual values, in general, to have an approximation of the size of the potential overestimation.

${ }^{13}$ Respondents in France and Switzerland who stated zero WTP were recorded as respondents with WTP=1\%.
} 
ENV/WKP(2014)13

Table 5. Factors explaining WTP for organically labelled fruit and vegetables

\begin{tabular}{|c|c|c|}
\hline & $\begin{array}{l}\text { Marginal effect } \\
\text { (Tobit estimation) }\end{array}$ & $\begin{array}{l}\text { Marginal effect } \\
\text { (Tobit estimation } \\
\text { without France and Switzerland) }\end{array}$ \\
\hline Age of respondents & 0.002 & 0.018 \\
\hline $\begin{array}{l}\text { Education } \\
\text { (number of years completed } \\
\text { after high school) }\end{array}$ & $0.176^{*}$ & 0.146 \\
\hline $\begin{array}{l}\text { logINC } \\
\text { Gender } \\
(\text { male }=1)\end{array}$ & $\begin{array}{l}1.608^{\star \star \star} \\
-2.249^{\star \star \star}\end{array}$ & $\begin{array}{l}0.036 \\
-2.291^{\star \star \star}\end{array}$ \\
\hline $\begin{array}{l}\text { Children in the household } \\
\text { (children }<5 \text { present }=1 \text { ) }\end{array}$ & 0.161 & 0.084 \\
\hline Score on "trust" index & $1.801^{\star \star *}$ & $1.989^{* \star *}$ \\
\hline $\begin{array}{l}\text { Ranking environmental } \\
\text { concerns before health } \\
\text { concerns }\end{array}$ & $3.831^{* * *}$ & $3.244^{*}$ \\
\hline $\begin{array}{l}\text { Supporting the activities of an } \\
\text { environmental organisation }\end{array}$ & $6.755^{\star * *}$ & $6.241^{* * *}$ \\
\hline $\begin{array}{l}\text { Disagreement with the } \\
\text { statement "environmental } \\
\text { impacts are frequently } \\
\text { overstated" }\end{array}$ & -0.377 & -0.180 \\
\hline $\begin{array}{l}\text { Disagreement with the } \\
\text { statement "environmental } \\
\text { issues will be resolved in any } \\
\text { case through technological } \\
\text { progress" }\end{array}$ & -0.199 & -0.160 \\
\hline $\begin{array}{l}\text { Area of residence } \\
(\text { town }=1)\end{array}$ & $1.121^{*}$ & $2.393^{\star *}$ \\
\hline $\begin{array}{l}\text { Number of observations } \\
\text { Prob > F } \\
\text { Pseudo R2 }\end{array}$ & $\begin{array}{l}8905 \\
0.000 \\
0.013\end{array}$ & $\begin{array}{l}7146 \\
0.000 \\
0.008\end{array}$ \\
\hline
\end{tabular}

Note: ${ }^{* *} p<0.01,{ }^{* *} p<0.05,{ }^{*} p<0.10$ 


\section{FACTORS AFFECTING THE WILLINGNESS TO PAY FOR MEAT AND POULTRY WITH ANIMAL WELFARE LABELLING}

\section{The issue}

Respondents were asked to state the maximum percentage price increase they would be willing to pay for meat and poultry which are labelled as taking animal welfare into account, compared to conventional substitutes. The median WTP for meat and poultry that take animal welfare into account varies from $10 \%$ in several countries to $20 \%$ (in Switzerland) while the mean WTP varies from $20 \%$ in Australia to $31 \%$ in Switzerland. Respondents may have confused organic and animal welfare labelling when specifying the amount consumed. In a study of Danish scanner data on organic, free-range and battery cage eggs, Andersen (2011) finds that consumers may confuse organic and free-range, and that expressing trust in the animal welfare benefits of organic eggs does not change much the estimated willingness to pay. Her conclusion is that stated willingness to pay for animal welfare in eggs is mostly cheap talk. Income and age are barely significant. Only education and urban residence increases willingness-to-pay for organic and free-range eggs in that study. In the estimations presented in Table 6, we proxy trust in the label with the score on the general trust index. We also do a separate estimation on the Netherlands, the one country for which an animal welfare label was displayed (see Table C.4 in Appendix C).

\section{$2 \quad$ Estimation results}

In a similar manner to WTP for organic food, WTP for animal welfare labelled meat and poultry increases with participation in environmental organisations and the score on the general trust index and also with years of post-secondary education but with a much smaller marginal effect. WTP for animal welfare labelled products decreases with disagreement with the statement "environmental issues will be resolved in any case through technological progress" and WTP is also lower for male respondents. 
Table 6. Marginal effects of factors explaining WTP for animal welfare labelled meat and poultry - tobit estimation on the pooled sample

\begin{tabular}{|c|c|}
\hline & Marginal effect \\
\hline Age of respondents & 0.012 \\
\hline $\begin{array}{l}\text { Education } \\
\text { (number of years completed after high school) }\end{array}$ & $0.199^{*}$ \\
\hline $\log I N C$ & 0.748 \\
\hline $\begin{array}{l}\text { Gender } \\
(\text { male }=1)\end{array}$ & $-2.754^{* * *}$ \\
\hline $\begin{array}{l}\text { Children in the household } \\
\text { (children }<5 \text { present }=1 \text { ) }\end{array}$ & -0.291 \\
\hline Score on "trust" index & $1.664^{\star \star \star}$ \\
\hline $\begin{array}{l}\text { Supporting the activities of an environmental } \\
\text { organisation }\end{array}$ & $7.448^{* \star \star}$ \\
\hline $\begin{array}{l}\text { Disagreement with the statement "environmental } \\
\text { impacts are frequently overstated" }\end{array}$ & 0.085 \\
\hline $\begin{array}{l}\text { Disagreement with the statement "environmental } \\
\text { issues will be resolved in any case through } \\
\text { technological progress" }\end{array}$ & $-0.427^{*}$ \\
\hline $\begin{array}{l}\text { Area of residence } \\
(\text { town }=1)\end{array}$ & 0.740 \\
\hline $\begin{array}{l}\text { Number of observations } \\
\text { Prob > F } \\
\text { Pseudo R2 }\end{array}$ & $\begin{array}{l}7956 \\
0.000 \\
0.009\end{array}$ \\
\hline
\end{tabular}

The results on the estimation of the marginal effects on the WTP for animal welfare labelled products on the Dutch sample only are presented in Table C.4 in Appendix C. The only socio-demographic variable that is significant in explaining WTP for animal welfare labelled meat and poultry on this sample is the presence of children under 5 in the household, which has a negative effect on stated WTP for animal welfare labelled products. Instead, it is mainly environmental attitudes and behaviour that determine WTP. The level of WTP increases with: membership in environmental organizations, the trust index, and stronger environmental attitudes, as expressed by disagreement with the statement "environmental impacts are frequently overstated". 


\section{FACTORS AFFECTING FOOD WASTE}

In the questionnaire, respondents were also asked to approximate the proportion of food bought by their household that was thrown away (excluding non-edible parts of food, such as vegetable and fruit peel). While in most countries surveyed the median value is $10 \%$, the descriptive statistics show significant variations with the median ranging from $6 \%$ in France to up to $14 \%$ in Israel and 15\% in Korea. It is thus important to understand the determinants of food waste in order to encourage households to waste less food. An ordinary least squares estimation is applied on the continuous dependent variable. ${ }^{14}$

We could not test for policy instruments directly, but the impact of socio-demographic characteristics may indicate which groups to target for information campaigns. The pooled estimation results presented in Table 7 indicate that older respondents tend to waste less food. Income has no significant impact on the declared amount of food waste, but employment status has; the unemployed tend to waste less food. Male respondents declared that the household wasted less food, all else equal. Household size is not significant but the presence of children under 5 years of age has a positive significant impact on food waste. Agreement with the food waste importance statement in the survey has no significant effect in the pooled sample estimation. ${ }^{15}$ Voting and participating in an environmental organisation has no significant effect in the pooled sample estimation. Stronger environmental attitudes, as reflected by disagreement with the statements "environmental impacts are frequently overstated" and "environmental issues will be resolved in any case through technological progress" decrease the amount of declared food waste.

By comparison with Australia (the reference), the country dummy variables for Canada, Chile, Israel, Korea and Spain had a positive significant impact (results not displayed below), the largest being Korea. The country dummies for France and Switzerland have a significant negative impact on the amount of declared food waste. ${ }^{16}$

\footnotetext{
${ }^{14}$ With robust standard errors, since cluster weights are used together with country dummies. The cluster weights ensure that each country sample accurately reflects national statistics and that the pooled sample is unbiased.

${ }^{15}$ In the separate country estimations (not shown here), agreement with the statement reduces food waste in France, the Netherlands and in Switzerland. Surprisingly, agreement with the statement has a positive effect on food waste in Chile, Israel and Spain.

${ }^{16}$ The country dummies are consistent with the mean (and median) values for food waste in each country: Korea, Chile, Israel and Spain having the highest mean of food waste, whereas France and Switzerland have the smallest stated mean values of food waste.
} 
Table 7. Factors explaining the amount of declared food waste

\begin{tabular}{|c|c|}
\hline & Marginal effect \\
\hline Age of respondents & $-0.067^{\star \star \star}$ \\
\hline Education & $.223^{*}$ \\
\hline $\begin{array}{l}\text { (number of years completed after high school) } \\
\text { logINC }\end{array}$ & -329 \\
\hline Employed & $1.511^{* *}$ \\
\hline $\begin{array}{l}\text { Gender } \\
(\text { male }=1)\end{array}$ & $-1.686^{\star \star *}$ \\
\hline Household size & 0.356 \\
\hline $\begin{array}{l}\text { Children in the household } \\
\text { (children }<5 \text { present }=1 \text { ) }\end{array}$ & $1.978^{\star *}$ \\
\hline $\begin{array}{l}\text { Voting } \\
\text { (voted in elections the last year }=1 \text { ) }\end{array}$ & -1.243 \\
\hline $\begin{array}{l}\text { Agreement with the statement "Food waste has significant } \\
\text { negative environmental consequences" }\end{array}$ & $0.544^{*}$ \\
\hline $\begin{array}{l}\text { Disagreement with the statement "environmental impacts are } \\
\text { frequently overstated" }\end{array}$ & $-1.175^{\star \star *}$ \\
\hline $\begin{array}{l}\text { Disagreement with the statement "environmental issues will } \\
\text { be resolved in any case through technological progress" }\end{array}$ & $-0.616^{\star *}$ \\
\hline $\begin{array}{l}\text { Composts food waste } \\
\text { (Household usually composts its food waste }=1 \text { ) }\end{array}$ & $3.167^{* * *}$ \\
\hline constant & $21.883^{\star * \star}$ \\
\hline Number of observations & 8405 \\
\hline Prob $>F$ & 0.000 \\
\hline R-squared & 0.060 \\
\hline
\end{tabular}

Note: ${ }^{* \star *} p<0.01,{ }^{* *} p<0.05,{ }^{*} p<0.10$

A curious result arises in the pooled estimation with respect to whether the household composts or not. The a priori hypothesis is that composting would decrease food waste, but the inverse is found. The separate country estimations show that this positive relation holds in France, Japan, Korea and Spain. ${ }^{17}$ The ex ante hypothesis of a negative relationship between composting and food waste is confirmed only in the Swiss country estimation. For the other countries, composting is not a statistically significant factor in explaining the amount of food waste. There may be problems including composting as an explanatory variable since it is likely to be correlated with some of the other explanatory variables measuring food waste awareness and concern.

17 Separate country estimations are not provided here to save space but are available upon request. One possible explanation of this non-intuitive result may come from the positive correlation between expenditure on organic fruit and vegetables on the one hand and composting and food waste, on the other hand, which was observed in Japan, Korea, and Spain. Consuming large amounts of vegetables seems a necessary requirement for being able to compost large quantities, and fruit and vegetables are also perishable. 


\section{FACTORS AFFECTING THE DECISION TO COMPOST FOOD WASTE}

On average, $36 \%$ of the respondents indicate that their household usually composts food waste, ranging from $12 \%$ in Israel to almost $62 \%$ in Switzerland. A probit estimation is used to estimate the probability of responding yes to the question "Does your household usually compost your food waste?" 18

Table 8. Factors explaining the composting of food waste

\begin{tabular}{|c|c|}
\hline & Marginal effect \\
\hline Age of respondents & $0.003^{* * *}$ \\
\hline Education & 0.001 \\
\hline $\begin{array}{l}\text { (number of years completed after high school) } \\
\text { logINC }\end{array}$ & $-0.023^{*}$ \\
\hline $\begin{array}{l}\text { Employed } \\
(\text { employed }=1)\end{array}$ & 0.008 \\
\hline $\begin{array}{l}\text { Gender } \\
(\text { male }=1)\end{array}$ & -0.018 \\
\hline Household size & $0.024^{* * *}$ \\
\hline $\begin{array}{l}\text { Voting } \\
\text { (voted in elections the last year }=1 \text { ) }\end{array}$ & $0.054^{* * *}$ \\
\hline Supporting the activities of an environmental organisation & $0.125^{\star * *}$ \\
\hline Score on the food waste awareness index & $0.040^{* * *}$ \\
\hline $\begin{array}{l}\text { Ranking of environmental concerns high compared to other } \\
\text { issues facing the world }\end{array}$ & $0.012^{\star *}$ \\
\hline $\begin{array}{l}\text { Disagreement with the statement "environmental impacts } \\
\text { are frequently overstated" }\end{array}$ & -0.002 \\
\hline $\begin{array}{l}\text { Disagreement with the statement "environmental issues will } \\
\text { be resolved in any case through technological progress" }\end{array}$ & -0.004 \\
\hline $\begin{array}{l}\text { Waste charge } \\
\text { (household is charged for its waste according to volume or } \\
\text { weight=1) }\end{array}$ & $0.043^{*}$ \\
\hline $\begin{array}{l}\text { House } \\
\text { (living in detached or semi-detached house }=1 \text { ) }\end{array}$ & $0.157^{\star \star \star}$ \\
\hline $\begin{array}{l}\text { Area of residence } \\
(\text { town }=1)\end{array}$ & $-0.034^{\star *}$ \\
\hline Number of observations & 9144 \\
\hline Prob>chi2 & 0.000 \\
\hline Pseudo R2 & 0.141 \\
\hline
\end{tabular}

The estimation includes country-specific dummy variables and use of sample weights.

The estimation results in Table 8 indicate that respondents that are more likely to compost are older, with larger households and with less income. Living in a detached or semi-detached house (indicating the presence of a garden) also increases the probability to compost food waste. Respondents in rural areas are also more likely to compost compared to respondents living in urban areas. Several attitudinal and behavioural variables have a significant impact on composting: awareness of a food waste problem, participation in an environmental organisation, and also voting in elections. Ranking the environment as the most important issue facing the world also increases composting, whereas the other attitudinal measures were not statistically significant in explaining the composting decision. The separate country

\footnotetext{
${ }^{18}$ The marginal effects are evaluated at the means of the explanatory variables, apart for the dummy variables, for which the marginal impact is evaluated when going from 0 to 1.
} 
estimations confirm the above results and do not yield any additional insights. We include one policy variable that may affect the decision to compost food waste, i.e., if the household is charged for its waste according to volume or weight. ${ }^{19}$ A household that is charged for its waste according to volume or weight is significantly more likely to compost its food waste. The statistical significance of this policy instrument is not as large as for the other factors that explain composting of food waste, but quantitatively, the marginal effect is larger than for the demographical factors and about the same size as the variables measuring environmental attitudes (but not behaviour).

\footnotetext{
${ }^{19}$ The reference being a flat fee or some other fee non related to actual volume or weight of the waste.
} 


\section{DISCUSSION AND COMPARISON WITH PREVIOUS RESULTS}

Compared to previous results in the literature, the results from the EPIC 2011 survey confirm the central role of environmental attitudes and behaviours (such as participation in environmental organizations) as explanatory variables in using and trusting organic labels and the decision to purchase organic or not.

As for the explanatory factors for the actual expenditure share on fruit and vegetables, the EPIC 2008 survey found no or little effect from demographic variables. Whereas our main findings emphasize the prominence of attitudes and behaviour we do find that age, education and gender explain the use of an organic label. The decision to purchase organic food strongly depends on income which could indicate that price still acts a barrier, despite more widespread distribution of organic products and a decrease in the observed price premia. The marginal effects of the demographic variables are small, apart from income and the presence of children under 5 in the household. The literature indeed contains mixed results on demographics such as age and education (see Table 9), often because they are used to proxy environmental preferences that are not directly measured in the studies.

The results from the previous round of the EPIC survey implemented in 2008 showed that the effect of income on the actual expenditure share on fruit and vegetables was statistically significant and positive for fruit and vegetables. This result is confirmed on the data from the EPIC 2011 survey. We tested for the presence of children under 5 years of age and it was significant, a result in line with Loureiro et al. (2001). Ranking environmental concerns before health concerns in food choices positively explains the expenditure level on organic food. This is a new result but coherent with the analysis of the EPIC 2008 survey which found no statistical effect of health rank on expenditures on fruit and vegetables. Environmental attitudes and behaviour have a larger marginal effect on expenditures than on the probability to buy organic, which recalls the results of Durham (2007) that environmental motivations are influential in determining higher levels of purchases. Also another previous study (Welsch and Kuhling, 2009) found a positive impact of environmental attitudes on the consumption of organic food.

A comparison with the results of the EPIC survey of 2008 as regards the WTP for organic food is not straightforward since the WTP question was different in the two surveys. Some kind of comparison can be made for the six countries that were present in the 2008 survey. Since the question was open-ended in the 2011 EPIC survey, this may explain why respondents in general were willing to pay more for organic fruit and vegetables than in 2008 .

In any case we do not wish to draw any conclusions on causality related to increased food safety concerns. What we can compare, though, is the relative importance of different factors in explaining WTP, and the results are corroborated by the previous survey results. We find that WTP for organic fruit and vegetables increases with education and income; and that men declare a lower WTP. The literature indeed normally finds that WTP is higher for women respondents (Govindasamy and Italia, 1999). The results on education and income are mixed, though, although recent studies tend to find a positive effect from income (OECD, 2011). The marginal effect of environmental behaviour (membership in an environmental organisation) is much higher than that of the demographic characteristics and income, which confirms the central role of attitudes discussed in the literature. 
As no questions were asked on the expenditure share on meat and poultry labelled animal welfare (nor on WTP) in the EPIC 2008 survey, we can only compare the results presented here to the literature. Most studies on animal welfare find only gender and income statistically significant (see Table 10), but their effect is often ambiguous (Gracia et al., 2011). Age sometimes also has a positive effect on WTP for animal welfare labelled products. Here we find that expenditures on animal welfare labelled meat and poultry increase with age and education, but that income is not significant. We also find that expenditure increases with the strength of environmental concern and attitude variables that not always are measured and included in other studies. In one of the few studies to include several attitudinal variables, Verhoef (2005) did not find any impact of environmental variables on the purchase decision and only a weak effect on purchasing intensity (expenditures). We do share the conclusions that few demographic variables matter in explaining expenditure, apart from being male, which decreases the likelihood to purchase animal welfare labelled products. Willingness to pay for animal welfare is found to increase with education (also found in Gracia et al., 2011) and the strength of environmental attitudes and behaviour. This last factor is important and it has not been included in previous studies. Income had no significant effect on willingness to pay for animal welfare, contrary to Chilton et al. (2006) and Gracia et al. (2011), but these studies did not control for environmental attitudes. 
Table 9. Summary of results of the most recent studies on organic food

\begin{tabular}{|c|c|c|c|c|c|c|c|c|c|c|c|c|}
\hline & Income & Age & Male & $\begin{array}{l}\text { Educa } \\
\text { tion }\end{array}$ & $\begin{array}{l}\mathrm{HH} \\
\text { size }\end{array}$ & $\begin{array}{c}\text { Children in } \\
\mathrm{HH}\end{array}$ & $\begin{array}{l}\text { Urban } \\
\text { residence } \\
\text { location }\end{array}$ & $\begin{array}{l}\text { Primary } \\
\text { shopper }\end{array}$ & $\begin{array}{l}\text { Env. } \\
\text { Attitud } \\
\text { es }\end{array}$ & $\begin{array}{l}\text { Belief in health } \\
\text { benefits }\end{array}$ & $\begin{array}{l}\text { Belief in environmental } \\
\text { benefits }\end{array}$ & $\begin{array}{l}\text { Final sample size, } \\
\text { country }\end{array}$ \\
\hline Expenditures: & & & & & & & & & & & & \\
\hline $\begin{array}{c}\text { Thompson and Kidwell } \\
\text { (1998) }\end{array}$ & & NS & NS & - & & + & & & & & & $\begin{array}{l}340 \text { shoppers (actual } \\
\text { choices); US }\end{array}$ \\
\hline $\begin{array}{c}\text { Govindasamy and Italia } \\
\text { (1999) }\end{array}$ & + & - & - & + & - & - & & & & & & 291; US \\
\hline Zepeda and Li (2007) & NS & - & NS & + & & $-(6-17)$ & & & & & & 680; US \\
\hline $\begin{array}{l}\text { Gracia and De Magistris } \\
\text { (2008) Buying decision }\end{array}$ & - & NS & NS & NS & NS & & & & + & + & NS & 200 ; Italy \\
\hline $\begin{array}{l}\text { Gracia and De Magistris } \\
\text { (2008) Regular cons. }\end{array}$ & NS & NS & NS & NS & NS & & & & NS & NS & + & 200; Italy \\
\hline $\begin{array}{c}\text { Dettman (2008) Buying } \\
\text { decision }\end{array}$ & + & NS & & + & & NS & & & & & & $\begin{array}{c}\text { Scanner data on } \\
14110 \text { households; US }\end{array}$ \\
\hline $\begin{array}{c}\text { Dettman (2008) } \\
\text { Expenditure share }\end{array}$ & - & $\begin{array}{l}\text { Exclud } \\
\text { ed }\end{array}$ & & + & & Excluded & & & & & & \\
\hline Wier et al. (2008) & & + & & + & & + & & & & & & $\begin{array}{c}\text { Scanner data } \\
\text { combined with survey } \\
\text { on the same HH; } \\
\text { Denmark, UK }\end{array}$ \\
\hline Smith et al. (2009) & + & NS & & + & & $+(<6$ years $)$ & + & & & & & $\begin{array}{c}\text { Scanner data on } 7296 \\
\text { HH; US }\end{array}$ \\
\hline OECD Survey 2008 & + & - & NS & NS & & & NS & & & & & \\
\hline OECD Survey 2011 & + & + & NS & NS & & $+(<5$ years $)$ & NS & & + & \multicolumn{2}{|c|}{$\begin{array}{c}\text { Ranking environ. concerns higher than } \\
\text { health concerns increases the prob. of } \\
\text { buying organic }\end{array}$} & $\begin{array}{l}\text { 8337; } 11 \text { OECD } \\
\text { countries }\end{array}$ \\
\hline
\end{tabular}


Table 10. Determinants of WTP for animal welfare. Summary of results of previous studies

ENV/WKP(2014)13

\begin{tabular}{|c|c|c|c|c|c|c|c|c|c|c|}
\hline & Income & Age & Male & Education & $\begin{array}{l}\mathrm{HH} \\
\text { size }\end{array}$ & $\begin{array}{c}\text { Children in } \\
\mathrm{HH}\end{array}$ & $\begin{array}{l}\text { Urban residence location } \\
\text { (versus rural) }\end{array}$ & $\begin{array}{l}\text { Attitudes to } \\
\text { the } \\
\text { environment }\end{array}$ & $\begin{array}{l}\text { Primary } \\
\text { shopper }\end{array}$ & (Final) sample size, country \\
\hline Chilton et al. (2006) & + & + & & & & & & & NS & 200 respondents ; UK \\
\hline $\begin{array}{l}\text { Lagerkvist et al. } \\
\qquad(2006)\end{array}$ & NS & NS & + & NS & NS & $\begin{array}{c}\text { NS } \\
\text { (<20 years) }\end{array}$ & & & - & 285 respondents ; Sweden \\
\hline Carlsson et al. (2007) & NS & NS & NS & NS & NS & $\begin{array}{c}\text { NS } \\
\text { (<20 years) }\end{array}$ & & & NS & 710 respondents ; Sweden \\
\hline Liljenstolpe (2008) & - & NS & + & & NS & NS & NS & & & 1250 respondents; Sweden \\
\hline Nocella et al. (2010) & NS & + & - & NS & + & & & & & $\begin{array}{l}1294 \text { respondents; France, Germany, } \\
\text { Italy, Spain, UK }\end{array}$ \\
\hline Liljenstolpe (2011) & - & & + & & & & & & & 1250 respondents ; Sweden \\
\hline Gracia et al. (2011) & $+/ \mathrm{NS}$ & $+/$ NS & NS/- & $\mathrm{NS} /+$ & NS/- & & & & & $\begin{array}{l}\text { Experimental auction with } \\
350 / 370 \text { obs.; Spain }\end{array}$ \\
\hline Andersen (2011) & NS & + & & NS & & & + & & & $\begin{array}{c}\text { scanner panel data of } 844 \mathrm{HH} ; \\
\text { Denmark }\end{array}$ \\
\hline $\begin{array}{c}\text { Makdisi and } \\
\text { Marggraf (2011) }\end{array}$ & + & + & NS/- & + & + & & NS & & & 300 respondents ; Germany \\
\hline $\begin{array}{l}\text { OECD Survey } 2011 \\
\text { WTP }\end{array}$ & NS & NS & - & + & & NS & NS & + & & $\begin{array}{l}7956 \text { observations ; } 11 \text { OECD } \\
\text { countries }\end{array}$ \\
\hline
\end{tabular}




\section{KEY FINDINGS AND POLICY IMPLICATIONS}

The only policy instrument that we can analyse for the consumption of organic food and animalwelfare-labelled products is labelling, but there may have been other policies in place at the time of the survey, such as information/publicity campaigns, subsidies or restrictions (direct interventions) on certain types of products. The analysis has not been able to control for those, and we believe that information on these other policies would be very useful. As for now, we can only capture this by country dummy variables.

It is not straightforward to assess the impact of labels since label recognition, trust and use are endogenous to the decision to purchase organic fruit and vegetables. The estimation results indeed show that ranking environmental concerns as the most serious issue facing the world today is the one factor that consistently matters for label recognition, understanding, trust and use. The estimation results on expenditure on organic fruit and vegetables showed that income, the presence of young children in the household and age increase expenditure together with environmental attitudes. The level of organic expenditures decreases if the respondent is male and it varies positively with disagreement with the statement "environmental impacts are frequently overstated". Across the different estimations (on the pooled sample, on the EU countries in the sample, and on individual countries) a high score on the general trust index significantly increases expenditure on organic fruit and vegetables. We also tried to assess the relative importance of environmental versus health concerns in determining the expenditure share on organic fruit and vegetables by including a variable accounting for whether environment or health was ranked as the most important variable in the respondent's food choices. In all estimations, ranking environmental concern before health concerns in food choices turned out to have a statistically significant and positive effect on expenditures on organically labelled fruit and vegetables. This variable is derived from a general ranking of factors that are important in food choices, though, and we also tested for the explanatory power of individual health status (diabetes, obesity and cholesterol), but these variables were never significant in explaining expenditures on organic fruit and vegetables. There may exist a causal relationship in the other direction, though, since we find that being obese diminishes the probability to use the organic labels (robustness checks not shown here).

Expenditure on animal welfare labelled meat and poultry seems even more determined by environmental attitudes. The only socio-demographic variables that have a statistically significant impact on such expenditure are age and education. Male respondents also state lower expenditures on animal welfare labelled products. Interestingly enough, living in a rural area had no effect on neither the expenditure share of animal welfare labelled products nor on the WTP for such products.

Apart from working on improving the trust in labels, the results indicate which groups to target in order to increase the use of organic and animal welfare labels. Males and younger respondents were less likely to trust and to use labels, be it organic or animal welfare labels.

We also analysed determinants of food waste, which has become an important policy concern, especially in Israel, Korea and Sweden. Information campaigns intended to decrease food waste may be more effective if they focus on the young and on households with children under 5 years of age.

The decision to compost food waste is encouraged by households facing a waste fee based on volume or weight, as would be expected. The effect is negative and statistically significant, although not at the same level as some other explanatory factors (like the possibility of doing so by having a house or living in a rural area, or the strength of environmental behaviour). Nevertheless the marginal effect of a waste charge is almost equal to the one from scoring high on environmental attitudes measures or statements indicating awareness of food waste problems. 
ENV/WKP(2014)13

\section{REFERENCES}

Andersen, L.M. (2011), “Animal Welfare and Eggs - Cheap Talk or Money on the Counter?”, Journal of Agricultural Economics 62(3), 565-584.

Bennett, R. and D. Larson (1996), "Contingent Valuation of the Perceived Benefits of Farm Animal Welfare Legislation: An Exploratory Survey”, Journal of Agricultural Economics 47(2), 224-235.

Bennett, R. and R.J.P. Blaney (2003), "Estimating the Benefits of Farm Animal Welfare Legislation Using the Contingent Valuation Method", Agricultural Economics 29, 85-98.

Brown, Z. (2014), "Greening Household Behaviour: Cross-domain comparisons in environmental attitudes and behaviours", OECD Environment Working Papers, No. 68, OECD Publishing, Paris, http://dx.doi.org/10.1787/19970900.

Bunte, F.H.J., et al. (2010), "Limits to the Growth in Organic Sales”, De Economist 158, 387-410.

Carlsson, F., P. Frykblom and C.J. Lagerkvist (2007), "Consumer Willingness to Pay for Farm Animal Welfare: Mobile Abattoirs versus Transportation to Slaughter", European Review of Agricultural Economics 34(3), 321-344.

Chilton, S.M., D. Burgess and W.G. Hutchinson (2006), "The Relative Value of Farm Animal Welfare", Ecological Economics 59, 353-363.

Dettmann, R.L. (2008), “Organic Produce: Who's Eating It? A Demographic Profile of Organic Produce Consumers", paper presented at American Agricultural Economics Association Annual Meeting, Orlando, 27-29 July.

Durham, C. (2007), "The Impact of Environmental and Health Motivations on the Organic Share of Produce Purchases", Agricultural and Resource Economics Review 36(2), 304-320.

Ehreke I., B. Jaeggi and K. W. Axhausen (2014), “Greening Household Behaviour and Transport", OECD Environment Working Papers, OECD Publishing, Paris, http://dx.doi.org/10.1787/19970900.

Giannakas, K. (2002), "Information Asymmetries and Consumption Decisions in Organic Food Product Markets", Canadian Journal of Agricultural Economics 50(1), 35-50.

Govindasamy, R. and J. Italia (1999), "Predicting Willingness to Pay a Premium for Organically Grown Fresh Produce", Journal of Food Distribution Research 30(2), 44-53.

Gracia, A. and T. de Magistris (2008), "The Demand for Organic Foods in the South of Italy: A Discrete Choice Model", Food Policy 33, 386-396.

Gracia, A., M.L. Loureiro and R.M. Nayga (2011), "Valuing an EU Animal Welfare Label using Experimental Auctions", Agricultural Economics 42, 669-677. 
Griffith, R. and L. Nesheim (2008), "Household Willingness to Pay for Organic Products", CEPR Discussion Papers 6905.

Kriström B. and C. Kiran (2014), "Greening Household Behaviour and Energy", OECD Environment Working Papers, OECD Publishing, Paris, http://dx.doi.org/10.1787/19970900.

Lagerkvist, C.J., F. Carlsson and D. Viske (2006), "Swedish Consumer Preferences for Animal Welfare and Biotech: A Choice Experiment", AgBioForum 9(1), 51-58.

Liljenstolpe, C. (2008), "Evaluating Animal Welfare with Choice Experiments: An Application to Swedish Pig Production", Agribusiness 24(1), 67-84.

Liljenstolpe, C. (2011), "Demand for Value-Added Pork in Sweden: A Latent Class Model Approach", Agribusiness 27(2), 129-146.

List, J. and C.A. Gallet (2001), "What Experimental Protocol Influence Disparities Between Actual and Hypothetical Stated Values? Evidence from a Meta-Analysis", Environmental and Resource Economics 20, 241-254.

Loureiro, M. L., J. McCluskey and R. C. Mittelhammer (2001), “Assessing Consumer Preferences for Organic, Ecolabeled and Regular Apples”, Journal of Agricultural and Resource Economics 26(2), 404-416.

Makdisi, F. and R. Marggraf (2011), "Consumer Willingness-to-Pay for Farm Animal Welfare in Germany - The Case of Broiler", paper presented at German Association of Agricultural Economists $51^{\text {st }}$ Annual Conference, Halle, September 28-30.

Monier-Dilhan, S., et al. (2009), “Organic Food Consumption Patterns”, Journal of Agricultural \& Food Industrial Organization 9(1), 5.

Murphy, J.J., et al. (2005), “A Meta-Analysis of Hypothetical Bias in Stated Preference Valuation”, Environmental and Resource Economics 30(3), 313-325.

Nauges, C. (2014), “Greening Household Behaviour and Water", OECD Environment Working Papers, No. 73, OECD Publishing, Paris, http://dx.doi.org/10.1787/19970900.

Nocella, G., L. Hubbard and R. Scarpa (2010), "Farm Animal Welfare, Consumer Willingness to Pay, and Trust: Results of a Cross-National Survey", Applied Economic Perspectives and Policy 32(2), 275297.

OECD (2014), Greening Household Behaviour: Overview from the 2011 Survey - Revised edition, OECD Studies on Environmental Policy and Household Behaviour, OECD Publishing, Paris, http://dx.doi.org/10.1787/9789264214651-en.

OECD (2011), Greening Household Behaviour: The Role of Public Policy, OECD Studies on Environmental Policy and Household Behaviour, OECD Publishing, Paris, http://dx.doi.org/10.1787/9789264096875-en.

Onken, K.A., J.C. Bernard and J.D. Pesek (2011), "Comparing Willingness to Pay for Organic, Natural, Locally Grown, and State Marketing Program Promoted Foods in the Mid-Atlantic Region", Agricultural and Resource Economics Review 40(1), 33-47. 
Palatnik R.R. et al. (2014), "Greening Household Behaviour and Waste”, OECD Environment Working Papers, No. 76, OECD Publishing, Paris, http://dx.doi.org/10.1787/19970900.

Serret Y. and Z. Brown (2014), "Greening household behaviour: Overview of results from econometric analysis and policy implications", OECD Environment Working Papers, OECD Publishing, Paris, http://dx.doi.org/10.1787/19970900.

Smith, T.A., C.L. Huang and B.-H. Lin (2009), "Does Price or Income Affect Organic Choice? Analysis of U.S. Fresh Produce Users", Journal of Agricultural and Applied Economics 41(3), 731-744.

Teisl, M., J. Rubin and C.L. Noblet (2008), "Non-Dirty Dancing? Interactions between Eco-Labels and Consumers", Journal of Economic Psychology 29, 140-159.

Thompson, G. (1998), "Consumer Demand for Organic Foods: What We Know and What We Need to Know", American Journal of Agricultural Economics 80, 1113-1118.

Thompson, G. and J. Kidwell (1998), "Explaning the Choice of Organic Produce: Cosmetic Defects, Prices and Consumer Preferences", American Journal of Agricultural Economics 80, $277-287$.

Tonsor, G.I. and C. Wolf (2011), “On Mandatory Labelling of Animal Welfare Attributes”, Food Policy 36(3), 430-437.

Verhoef, P.C. (2005), "Explaining Purchases of Organic Meat by Dutch Consumers”, European Review of Agricultural Economics 32(2), 245-267.

Welsch, H. and J. Kuhling (2009), "Determinants of Pro-environmental Consumption: The Role of Reference Groups and Routine Behavior", Ecological Economics 69(1), 166-176.

Wier, M., et al. (2008), "The Character of Demand in Mature Organic Food Markets: Great Britain and Denmark Compared", Food Policy 33, 406-421.

Williams, P.R.D. and J.K. Hammitt (2000), "A Comparison of Organic and Conventional Produce Buyers in the Boston Area", Risk Analysis 20(5), 735-746.

Yue, C., F. Alfnes and H.H. Jensen (2009), "Discounting Spotted Apples: Investigating Consumers' Willingness to Accept Cosmetic Damage in an Organic Product", Journal of Agricultural and Applied Economics 14(1), 29-46.

Yue, C. and C. Tong (2009), "Organic or Local? Investigating Consumer Preference for Fresh Produce Using a Choice Experiment with Real Economic Incentives”, Hortscience 44(2), 366-371.

Zepeda, L. and J. Li (2007), "Characteristics of Organic Food Shoppers”, Journal of Agricultural and Applied Economics 39(1), 17-28. 


\section{APPENDIX A: ECONOMETRIC METHOD}

\section{Probit model}

The estimations of the probability to trust or to use a label are done using the probit method, with the dependent variable taking the value of 1 if the respondent trusts/uses the label, and zero otherwise.

The probit model specifies a latent variable

$y_{i}^{*}-\beta X_{i}+u_{i}$

and defines the probability as

$$
\begin{aligned}
& y=1 \text { if } y_{i}^{*}>0 \\
& y=0 \text { othenwise }
\end{aligned}
$$

We can then write the probability of $y$ being equal to 1 as

$\operatorname{Prob}\left(\mathrm{y}_{\mathrm{i}}=1\right)=\operatorname{Prob}\left(\mathrm{u}_{\mathrm{i}}>-\beta^{\prime} \mathrm{X}_{\mathrm{i}}\right)=1-\mathrm{F}\left(-\beta^{\prime} \mathrm{X}_{\mathrm{i}}\right)$

where $\mathrm{F}$ is the cumulative density function for $\mathrm{u}$. In the probit model, the error term is assumed normally distributed and the likelihood function uses a normal distribution for the cdf.

\section{Tobit model}

The estimations of expenditure and WTP are done using Tobit estimation. The Tobit estimation assumes there is a latent variable (unobservable to the econometrician) that decides whether there is a positive expenditure level or not. Denoting the latent variable by $\mathrm{y}^{*}$ :

$y^{*}-\beta X+\varepsilon$

where the error term is assumed normally distributed with mean 0 and variance $\sigma^{2}$.

The dependent variable y is observed dependent on whether the latent variable is positive or not:

$y=\left\{\begin{array}{lll}y^{*} & \text { if } & y^{*}>0 \\ 0 & \text { if } & y^{*} \leq 0\end{array}\right.$ 
The dependent variable can be censored from below and from above (in the question on expenditure, the lower bound is set at zero and the upper bound at 100, in percentage terms).

The Tobit estimation relies heavily on distributional assumptions. If the error term is not normally distributed, the estimator does not yield consistent estimates. For this particular application, the normality assumption seems correct from visual inspection of a plot of the WTP values presented in Figure 1.

Figure 1. Willingness-to-pay

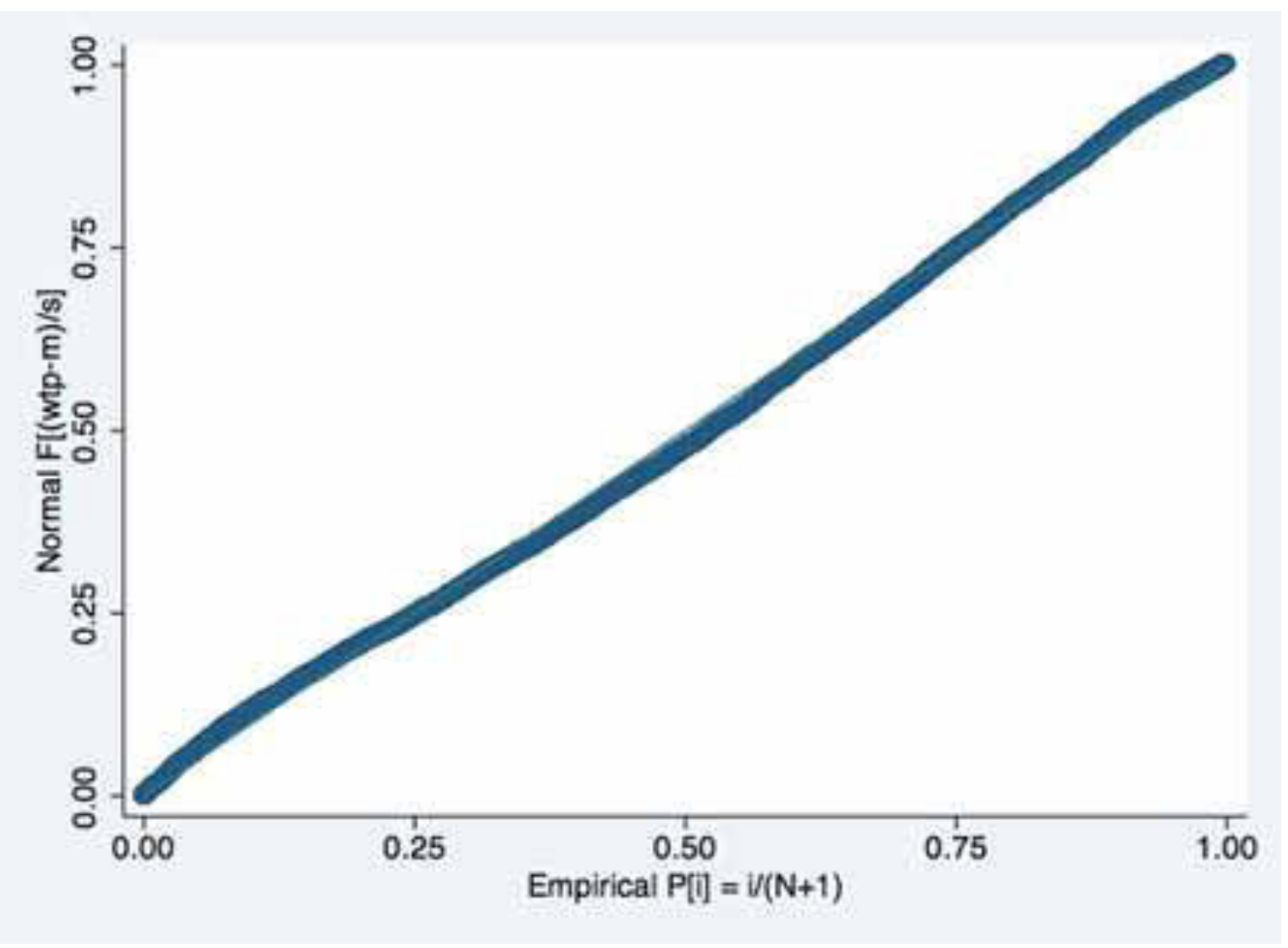




\section{APPENDIX B: VARIABLE DEFINITIONS}

Table B.1 Definitions of the variables used in the estimations

\begin{tabular}{|c|c|}
\hline Explanatory variable & Coefficient \\
\hline \multicolumn{2}{|l|}{$\begin{array}{l}\text { Socio-economic and } \\
\text { demographic factors: }\end{array}$} \\
\hline age & Age of the respondent. \\
\hline a05_year_post_schol & Years of post-secondary education. \\
\hline $\log \mathrm{INC}$ & Log of imputed household income. \\
\hline i_empl & Dummy variable equal to 1 if respondent is employed, otherwise zero. \\
\hline i_male & Dummy variable equal to 1 if respondent is male, reference is female. \\
\hline a3_hhsize_imp & Imputed household size. \\
\hline i_under5 & $\begin{array}{l}\text { Dummy variable equal to } 1 \text { if the household has children under } 5 \text { years of } \\
\text { age, otherwise zero. }\end{array}$ \\
\hline i_house & $\begin{array}{l}\text { Dummy variable equal to } 1 \text { if the respondent lives in a house, otherwise } \\
\text { zero. }\end{array}$ \\
\hline i_town & Dummy equal to 1 if the respondent lives in an urban area, otherwise zero. \\
\hline \multicolumn{2}{|c|}{$\begin{array}{l}\text { Stated attitudes, behaviour } \\
\text { and habits: }\end{array}$} \\
\hline b4_vote & $\begin{array}{l}\text { Dummy variable equal to } 1 \text { if the respondent has voted in the national, } \\
\text { local or municipal elections the last year, zero otherwise. }\end{array}$ \\
\hline b5_envir & $\begin{array}{l}\text { Dummy variable equal to } 1 \text { if the respondent has participated in or } \\
\text { donated money to an environmental organization, zero otherwise. }\end{array}$ \\
\hline b2_rank_env & $\begin{array}{l}\text { Dummy variable equal to } 1 \text { if the respondent has ranked environmental } \\
\text { concerns as the most serious issue facing the world today. }\end{array}$ \\
\hline hlthenvcomp & $\begin{array}{l}\text { A dummy variable equal to } 1 \text { if the respondent ranks environmental } \\
\text { concerns before health concerns in her food choices, equal to zero if the } \\
\text { opposite holds. Based on survey question F1. }\end{array}$ \\
\hline f3_waste & $\begin{array}{l}\text { An index measuring agreement with the statement "Food waste has } \\
\text { significant negative environmental consequences"; higher value indicates } \\
\text { more agreement. }\end{array}$ \\
\hline b6_env_att2 & $\begin{array}{l}\text { Measures disagreement with the statement "Environmental impacts are } \\
\text { frequently overstated"; higher value indicates a stronger environmental } \\
\text { attitude. Based on survey question b6. }\end{array}$ \\
\hline b6_env_att6 & $\begin{array}{l}\text { Measures disagreement with the statement "Environmental issues will be } \\
\text { resolved in any case through technological progress"; higher value } \\
\text { indicates a stronger environmental attitude. Based on survey question b6. }\end{array}$ \\
\hline f4_compost & $\begin{array}{l}\text { Dummy variable equal to } 1 \text { if the household usually composts its food } \\
\text { waste, zero otherwise. }\end{array}$ \\
\hline b7_trust & $\begin{array}{l}\text { Index measuring the general level of trust, a higher score indicates higher } \\
\text { trust. }\end{array}$ \\
\hline
\end{tabular}




\section{APPENDIX C: ADDITIONAL ESTIMATION RESULTS}

Table C.1 Marginal effects of factors explaining trust in and use of either the old or the new EU organic label

\begin{tabular}{|l|l|l|}
\hline & Trust the label & Use the label \\
\hline age & $0.002^{* *}$ & $0.001^{*}$ \\
\hline a05_year_post_schol & $0.006^{* *}$ & $0.006^{* *}$ \\
\hline logINC & 0.020 & 0.018 \\
\hline i_male & $-0.090^{* * *}$ & $-0.077^{* * *}$ \\
\hline b5_envir & $0.190^{* * *}$ & $0.184^{* * *}$ \\
\hline b7_trust & $0.031^{* * *}$ & $0.019^{* * *}$ \\
\hline b2_rank_env & $0.101^{* * *}$ & $0.115^{* * *}$ \\
\hline i_town & -0.012 & -0.014 \\
\hline & & \\
\hline Number of observations & 3672 & 3672 \\
\hline Prob>chi2 & 0.000 & 0.000 \\
\hline Pseudo R2 & 0.067 & 0.078 \\
\hline
\end{tabular}

${ }^{* * *} p<0.01,{ }^{* *} p<0.05,{ }^{*} p<0.10$

Table C.2 Marginal effects of factors explaining the trust and use of either Australian organic label

\begin{tabular}{|l|l|l|}
\hline & Trust the label & Use the label \\
\hline age & 0.001 & 0.001 \\
\hline a05_year_post_schol & 0.004 & 0.004 \\
\hline logINC & -0.001 & -0.002 \\
\hline i_male & $-0.091^{* * *}$ & $-0.076^{* * *}$ \\
\hline b5_envir & $0.203^{* * *}$ & $0.200^{* * *}$ \\
\hline b7_trust & $0.029^{* * *}$ & $0.020^{* *}$ \\
\hline b2_rank_env & 0.066 & $0.084^{* *}$ \\
\hline i_town & 0.045 & 0.039 \\
\hline & & \\
\hline Number of observations & 876 & 876 \\
\hline Prob>chi2 & 0.000 & 0.000 \\
\hline Pseudo R2 & 0.064 & 0.092 \\
\hline
\end{tabular}

${ }^{* * *} p<0.01,{ }^{* *} p<0.05,{ }^{*} p<0.10$ 
ENV/WKP(2014)13

Table C.3 Marginal effects of factors explaining the trust and use of the animal welfare label in the Netherlands

\begin{tabular}{|l|l|l|}
\hline & Trust the label & Use the label \\
\hline age & -0.000 & $0.005^{*}$ \\
\hline a05_year_post_schol & -0.003 & -0.003 \\
\hline logINC & 0.021 & 0.053 \\
\hline i_male & $-0.091^{* *}$ & -0.063 \\
\hline b5_envir & -0.006 & 0.079 \\
\hline b7_trust & $0.033^{* *}$ & $0.061^{* *}$ \\
\hline b2_rank_env & $0.060^{*}$ & $0.218^{* * *}$ \\
\hline i_town & 0.018 & -0.011 \\
\hline & & \\
\hline Number of observations & 271 & 260 \\
\hline Prob>chi2 & 0.0182 & 0.0249 \\
\hline Pseudo R2 & 0.0957 & 0.0588 \\
\hline
\end{tabular}

${ }^{\star * \star} p<0.01,{ }^{* \star} p<0.05,{ }^{*} p<0.10$

Table C.4 Factors explaining WTP for animal welfare labelled meat and poultry in the Netherlands

\begin{tabular}{|l|l|l|}
\hline & $\begin{array}{l}\text { Marginal effect on the } \\
\text { probability of WTP for AW- } \\
\text { labelled meat and poultry }\end{array}$ & $\begin{array}{l}\text { Marginal effect on the level of } \\
\text { WTP }\end{array}$ \\
\hline age & -0.002 & -0.082 \\
\hline a05_year_post_schol & -0.003 & -0.129 \\
\hline logINC & -0.009 & -0.358 \\
\hline i_male & 0.041 & 1.697 \\
\hline i_under5 & $-0.102^{* *}$ & $-3.888^{*}$ \\
\hline b5_envir & $0.178^{* * *}$ & $9.923^{* * *}$ \\
\hline b7_trust & $0.055^{* * *}$ & $2.286^{* * *}$ \\
\hline b6_env_att2 & $0.033^{* *}$ & $1.399^{* *}$ \\
\hline b6_env_att6 & -0.011 & -0.472 \\
\hline i_town & 0.038 & 1.579 \\
\hline & & \\
\hline Number of observations & & 686 \\
\hline Prob>F & & 0.000 \\
\hline Pseudo R2 & & 0.018 \\
\hline
\end{tabular}

${ }^{* * *} p<0.01,{ }^{* *} p<0.05,{ }^{*} p<0.10$ 


\section{APPENDIX D: DATA SOURCES AND LIMITATIONS}

Based on a sample of more than 12000 respondents in eleven countries, ${ }^{20}$ this thematic report summarises main results on energy from the 2011 OECD periodic surveys on Environmental Policy and Individual Behaviour Change (EPIC) and draws evidence-based policy recommendations. ${ }^{21}$ It builds on earlier work and supplements the overview of the 2011 survey data presented in OECD (2014). ${ }^{22}$

As in all studies involving primary data collection, there can be a sample bias when implementing a survey. Rigorous efforts were made at stratification and quota sampling. The sampling strategy involved stratification across region, gender, age and socio-economic status. The degree to which the country-level samples are representative of the national population is presented for a number of key variables in OECD (2014) in Annex B. However, in some countries (e.g. Chile and Switzerland) not all of these parameters could be included. Nonetheless, as Annex B in OECD (2014) shows, deviations in excess of 20per cent from representativity across these variables, for which quotas were set, were very limited. Response bias can be a second concern. It should be noted that such a bias is not specific to using internet panel-based surveys and responses can be biased by the interviewer in face-to-face interviews and telephone surveys. Given that the subject matter of the OECD survey is not related to information technologies or Internet, except for a very small number of questions (i.e. investment in "smart" meters), there is little reason to believe that this would result in a systematic bias.

It is also important for the reader to bear in mind the fact that all of the data used in the analyses reported here are based upon survey responses. This survey elicited respondents' stated preferences and perceptions. Therefore statistics reported here which relate to objective, verifiable indicators should be interpreted with caution and in some cases there may be 'measurement error'. On the one hand, this may relate to the dependent variable used in the studies. For example, estimates of waste generation and recycling rates may be inexact for some respondents. Similarly, estimates of the percentage of fresh fruit and vegetables consumed which is organic may also be inexact. On the other hand, some respondents may be mistaken about the precise nature of the policy measures to which they are subject. For example, it is possible that some respondents may not be aware that a given policy exists in their country. Similarly, some respondents may mistakenly believe that a policy exists in their country, when in fact it does not. However, it is important to note that for all questions in which there was significant potential for such "measurement error", respondents were given the option to respond that they "did not know" if such a policy was in place. This may relate to both "carrot" (i.e. grants for investment in energy-efficient devices, scrappage bounties for motor vehicles) and "stick" approaches (i.e. price-based measures). Given the large sample size, such observations should not affect the results in an important way. However, in order to ensure robustness of the results, a large number of models were estimated, including models with different country samples. Attention is drawn to important differences.

In general, readers should view these data as exactly what they are: the self-reported behaviours, attitudes and perceptions of representative samples of households from eleven OECD countries. Bearing the limits of such data in mind, it is important to recognise their advantages: information on households' knowledge and perceptions about environmental issues - increasingly recognised as a crucial factor for better understanding behavioural responses to environmental policies - is rarely analysed at such level of detail. Moreover, for many variables such as discrete choices about whether or not a given purchase has been made, there is likely to be very little deviation from a more formal household consumer survey.

\footnotetext{
20 Australia, Canada, Chile, France, Israel, Japan, Korea, the Netherlands, Spain, Sweden and Switzerland. Approximately 1000 households were surveyed in each country.

${ }^{21}$ The first survey was carried out in 2008 in ten countries with a sample of more than 11000 respondents and the main results were presented in the OECD (2011).

22 The full 2011 EPIC Survey questionnaire in English is provided in OECD (2014) in Annex A.
} 